\title{
THE "DOUBLE BEING" OF THE HUMAN BEING: CULTURE AS THE BASIS FOR BECOMING A PERSONALITY
}

\begin{abstract}
The main purpose of this article is to prove that one can become a personality only through culture. The authors propose to regard culture as a relatively autonomous spiritual sphere, which transcends the narrow requirements of the concrete society in its historical limitations. They argue that personality is the highest level of human development to emerge in culture, whereas the level of a biosocial organism is provided by society. The authors claim that only culture, be it religious or secular, contains an existential and spiritual imperative which demands each human being to realize one's own potential humanity. They explain why in a postmodern world culture becomes an "existential choice" of each human being, depending on one's free will: to inherit the culture, to become a human being of humanity or not. In the Free school of philosophy and culture seminars (Odesa, Ukraine), the authors propose to enter the field of culture through the mutual interpretation of a chosen masterpiece of world literature and to link its message with our lives.
\end{abstract}

Keywords: personality, culture, Existenz, spirit, biosocial, human being, humanity

1. Introduction. 2. Empirical and Spiritual Self. 3. Culture and Spirituality. 4. Personality structure. 5. Spiritual Birth. 6. Conclusion.

\section{INTRODUCTION}

The current crisis is systemic. The prevailing technological civilization has set clear limits for the development of humans - it still needs our intellectual abilities, the so-called creativity, but it no longer needs us as integral personalities, or even individuals, preoccupied with the problem of identity. In principle, it could have done without humans at all, but it still needs them as a mediating link, a drive belt in the mechanics of a technological society that links all its sides together. However, this fundamental 'human uselessness' within the framework of the technological system is becoming more and more 
obvious, and the 'death of the subject' and 'of the human being' proclaimed by postmodernists are just philosophical expressions of what has long been happening in reality, which now acquires the formidable features of an anthropological catastrophe. The one who will emerge as a result of this disaster has already received the name posthuman. Thus, the category of personality, as well as all our previous categories of the human sciences, seems inappropriate in the discourse of posthumanism.

The authors of this article believe that only a holistic, 'focused' personality can consciously resist the destructive tendencies of the crisis of society and human being. However, the very notion of the personality becomes quite problematic in contemporary society. Yet, we will not dwell here on the external problems of being a personality. What is more significant is that it becomes increasingly difficult for a potential personality to find and realize the deep foundations of one's being.

As we know, existential philosophy was responsive to the emergence of humans without soil, to the loss of fundamental values and traditional guidelines, offering us the risk of being in conditions of our own assumed freedom and responsibility. Though, the individual can go quite far in denying everything universal in this risky selfaffirmation. Some very important link seems to be missing in the existential mode of philosophizing, such as Sartre's or Heidegger's. What is missing is the 'spiritual reality,' that is, the 'reality of culture' in which humans are to be rooted with invisible roots (in contrast to the soil of tradition and order of society). However, the omission of this link does not seem random. After all, existentialism itself was a traumatic reaction to the fall of the Babylonian tower of European culture under the bombs and dynamite of the First World War. Attitude to culture was at least ambiguous, it was considered rather as a side guilty of violence. Of course, it was society to blame for the violence, but existentialists, as well as Freud, did not make too 
subtle distinctions and, as a result, the baby was thrown out with the bathwater.

We are inclined to consider culture as a relatively autonomous spiritual sphere, not only supra-biological but also supra-social, going far beyond the narrow requirements of the concrete society in its historical limitations. Culture, together with its values, ideals, meaningful intentions, and voices, calls somewhere and appeals directly to the human being. It is a sphere within which personality is able to live spiritually, communicate, define herself, search for her 'human image' not by arbitrary choice, but as a human being of humanity. However, having drawn such an ideal image of culture, we cannot help but see that something perhaps irreparable has happened to culture. There is no doubt that the basis of all crises, social, civilizational, and anthropological, is the crisis of culture. "The crisis of culture is such a state when its universals are losing power over people; when the vital activity of the latter ceases to correspond to cultural norms and patterns." ${ }^{1}$ Those, who wrote about the crisis, also use other expressions: 'mistrust of the grand narratives' (F. Lyotard) or 'the death of God,' which F. Nietzsche himself expressed in The Will to Power as follows: "the highest values devaluate themselves." 2 This means that they ceased to be 'higher,' governing, that the hierarchy of higher and lower is lost, and the value order, about which Max Scheler was speaking, collapsed. Contemporary Polish philosopher Jan Krasicki writes: "The death of God does not occur in heaven, but here on earth. It begins with a narrowing of the horizons of our being, aspirations, and ambitions. It begins with ignoring impulses

1 V. Porus, Crossroads of methods. Experiences of Interdisciplinarity in the Philosophy of Culture, Canon + ROOI Rehabilitation, Moscow 2013, 257.

2 F. Nietzsche, The Will to Power, trans. W. Kaufmann and R.J. Hollingdale, Vintage Books, New York 1968, 9. 
of the heart, with dulling of sensitivity to Beauty, to that which is greater than ourselves, to the distant."3

It seems to us, that while philosophers were talking about the 'loss of metanarratives,' 'death of God,' 'death of the subject,' 'crisis of culture,' some other unnoticed event has happened. Speaking about the crisis, thinkers usually believe that it is the highest point of the disease, after which recovery is possible. Yet, death is possible too. Moreover, it seems that we have to talk about the 'death of culture,' which came so asymptomatically, so quietly that we did not have time to notice it. However, if we will look at the life of modern society, we will see that it no longer needs culture for the legitimization of certain social actions. Culture, in its former meaning of 'high culture,' is no longer needed for the formation of the lifestyle of millions of people - for media technologies have replaced culture.

According to Krasicki: "God died in sociology, in politics, in the works of Karl Schmitt, in medicine, in genetics. But not only a certain way of organizing relationships between people, but also an understanding of human life as a whole died." 4

Such an image of the world and system of relations that are set by media do not need "an understanding of human life." It is enough that people catch on the go the momentary impulse sent to them and instantly react to it. But this state of affairs cannot suit us. Therefore, the questions that we ask in this article are the following: Can I still be a personality after the death of culture? What is personality, what decisive steps constitute it? Isn't the spiritual being of personality connected with culture in the most intimate way? In such a case, does it not become impossible today? What is culture understood precisely as the space of personal spiritual being? Isn't a living culture

3 J. Krasicki, Mind and Other. Essays on Russian and European Thought, Russian Christian Academy for the Humanities Publishing House, St. Petersburg 2015, 230.

4 Ibidem, 221. 
a somewhat forceful, energetic field within which the clot of the personal spirit is concentrated?

Talks about the devaluation or inflation of values mean that there is no gold guarantee behind them anymore. What is such a gold guarantee? The belief in the unconditionality and high truth of spiritual values. Let's make a point that culture, both religious and secular, like a beautiful picture, is hanging on the 'nail of faith,' and inevitably falls if faith is absent. However, faith cannot be given or set. It is born out of spiritual freedom.

In this article, we could hardly be able to answer all these questions. However, it is impossible to limit ourselves only to one of them. The themes of personality-and-culture, spiritual life, the spirit of a culture, Existenz-and-spirit, and their unity in the 'existentialspiritual Self,' are inextricably intertwined in life itself.

\section{EMPIRICAL AND SPIRITUAL SELF}

Culture is alive, as long as it has the right, both in its religious and secular invariants, to demand to rise above the empirical life, to look at our routine from the height of the possible, proper, ideal, and act accordingly. If we try to understand the basis of the need to transcend ourselves and the world as it is in itself, in its empirical givenness, we will inevitably come to the idea of a 'double ontology' of human reality: both human being and the world are simultaneously given in their unconditional necessity and their possible freedom. We will then be able to see a second, free human reality with 'spiritual eyes' in the ideal 'mirror' of culture. We call a personality not the pragmatist individual, who pursues one's goals ignoring the requirements of culture, but the individual who is able to maintain the ideal requirements of culture and follow them where it is unprofitable and even dangerous. Personality sets the bar high.

"The establishment of moral rules based on categorical imperative implies a subjunctive mood (the famous als ob). I must act as if I lived 
in a world where moral order has been established." 5 In other words, one must act 'as if' God existed. But here we face a contradiction between critical and practical reason, because we often follow the dictates of the spirit of a culture that are contrary to reason and its calculations. Or, as one might say, we face a contradiction between the sphere of freedom and the sphere of necessity (natural and social). Kant would call this a contradiction between 'phenomena' and 'noumena.'

At the material, 'phenomenal' level, a human being as a 'physical being' (Kant's 'homo phaenomenon') falls under the laws of determination. At the spiritual, ideal, 'noumenal' level a human being is "thought in terms of his personality, that is, as a being endowed with inner freedom (homo noumenon), [and] is regarded as a being that can be put under obligation and, indeed, under obligation to himself (to the humanity in his own person)." ${ }^{6}$ That is, at that level a human being who is capable to proceed from a voluntarily chosen future reason for one's actions (teleology), i.e. capable of 'selfdetermination.' ${ }^{7}$ As a personality, human being belongs neither to nature, nor to oneself, but to 'humanity' as its representative.

These considerations are close to the idea of 'two Selves' within one's personality: the 'empirical Self' (Kant's "phaenomenon") and the 'spiritual Self' (Kant's 'noumenon'). The first Self is entrusted to the second one and is answerable to it as to God: "Every human being has a conscience and finds himself observed, threatened, and, in general, kept in awe (...) by an internal judge. (...) Such an ideal person (the authorized judge of conscience) must be a scrutinizer of hearts, since the court is set up within the human being." 8 Kant also

5 G. Gutner, The Concepts of Personality and Communicative Universals, in: Theology of Personality, Biblical Theological Institute, Moscow 2013, 110.

6 I. Kant, Practical Philosophy, trans. M.J. Gregor, Cambridge University Press, Cambridge 1996, 544.

7 Ibidem, 78.

8 Ibidem, 560-561. 
notes: «A human being who accuses and judges himself in conscience must think of a dual personality in himself, a doubled self which, on the one hand, has to stand trembling at the bar of a court that is yet entrusted to him, but which, on the other hand, itself administers the office of judge that it holds by innate authority." ${ }^{\prime 9}$ Our personality can only exist in culture as a special symbolic reality. At the physical level, the human being is a natural creature, a representative of biological species. And only at the level of culture does one become a representative of humanity. According to our definition, a human being of culture is a true bearer of the values and ideals contained in culture.

\section{CULTURE AND SPIRITUALITY}

Spirituality has become a worn-out concept because of its numerous random interpretations. The complaint about the lack of spirituality in contemporary society is allegedly associated with the total dominance of material interests. But we ask: should spirituality characterize the life of literally every human being? From our point of view, spirituality is not something inherent in us as, for example, hardness and heaviness are inherent in a stone. It is something given to each human being only potentially: everyone can be spiritual, but not everyone actually is, for spirituality characterizes the achievement of a certain level of human development (Russian existential psychologist D.A. Leontiev also stresses the facultative character of personality as the highest level of human development). Of course, this point of view is controversial and does not have the virtue of political correctness. It proceeds from the fact that spirituality is not something automatically given to humans, derived from society, but is born in efforts, in suffering, and can remain unborn. "We also note that the spiritual principle is not connected only with religion. Spirituality is the humanness

9 Ibidem, 560. 
in human being, and the lack of spirituality is its degeneration. Not only religious but also secular spirituality is possible." ${ }^{10}$

However, secular spirituality can by no means be identified with intellectual culture. In religious culture the situation is clearer: you need to 'acquire' the Holy Spirit. According to the secular paradigm, the 'spirit of culture' should embody in the spirit of personality too. In this case, the appearance of the spirit in a human being marks a certain event in one's transformation. You can be as educated and informed as you like, but still fail to reach a certain qualitative change, i.e. transformation. The 'saints' of secular culture, the true bearers of the spirit of a culture in Russia were called intelligentsia. Unfortunately, this word is devalued by the fact that nihilist revolutionaries were called intelligentsia too.

By recognizing the possibility of spiritual transformation for a human being of secular culture, we are allowed to talk about spirituality as a spirit acting in a human being. It is only in the 'field of culture' that spirituality is generated in a human being. Here, we enter the empirical facticity already transformed by culture, with the ability to transform it, that is, build culture from this facticity. This is precisely the transformation we have been discussing, the creative re-creation of life, and not the imposition of everyday life into a certain cultural framework.

All these inevitable distinctions between religious and secular culture, unfortunately, are connected with a long-standing cultural split. Secular culture is born as the heir of Christianity, but at the same time denies its inheritance, that is, its Christian core. Already in the IVth cent. St. Ambrose, an Archbishop of Milan, spoke of the incompatibility of Christian culture and culture as understood by Cicero. Unfortunately, this incompatibility survives in our time. Paul Tillich, among others, tried to overcome it by talking about the common roots of religion and secular culture. He tried to fill the 'gap'

10 V.Zh. Kelle, Culture and Freedom, Philosophy Journal (2008)1, 47. 
between them "by a fresh interpretation of the mutual immanence of religion and culture within each other."11 To this end, he developed the idea of 'theonomous culture'. Unlike autonomy and heteronomy, "theonomy asserts, that the superior law is, at the same time, the innermost law of man himself, rooted in the divine ground which is man's own ground: the law of life transcends man, although it is at the same time his own." 12

Similarly, V. Frankl speaks of a "religious sense deeply rooted in each and every man's unconscious depths" 13 or of an 'unconscious religiousness' "as a latent relation to transcendence inherent in man."14 Both existential thinkers rightly assert that God is at the deepest level of the unconscious, and not just at the level of consciousness. Such a view opens the possibilities of a new culture, in which the opposition between the religious and secular understanding of the world ceases to be radical.

\section{PERSONALITY STRUCTURE}

Let's now take a closer look at the personality structure. Russian poet F. Tyutchev, speaking of a 'double being' of the human being confronts the 'soul' and the 'heart.' We will use different expression to characterize the spiritual Self as the 'center' of a developed and self-aware personality and the 'ego.' As we have already said, the ego is connected with the biosocial level of existence. Russian writer M. Prishvin suggested in one of his diary notes that both plants and animals can have their Self. ${ }^{15}$ As well, a human being - even

11 P. Tillich, Religion and Secular Culture, The Journal of Religion 26(1946)2, 79.

12 Ibidem, 80.

13 V. Frankl, The Unconscious God. Psychotherapy and Theology, Hodder and Stoughton, London 1977, 10.

14 Ibidem, 60.

15 V. Vizgin, V. Prishvin and Philosophy, Center for Humanitarian Initiatives, Moscow, St. Petersburg 2016, 123. 
before consciousness develops - is as if shouting about oneself: 'I'! And this irrational, preconscious and pre-cultural Self longs for selfaffirmation, an endless and lawless one. But here it is part of the egoconsciousness, which, like a cunning animal, lives in society using all the powers of its mind for self-affirmation, seeking and finding all kinds of loopholes. In turn, this requires roundabout maneuvers and big sacrifices, the amount of which is not yet suspected. After all, the consciousness of a social functionary is predominantly rational, and it simply does not realize everything that does not pass through the filter of concepts and universal categories of the prevailing rational thought. The ego-consciousness should allow society to 'generalize' itself, to embed these filters in itself. And the individual, unique in humans as a very life that lives itself, reveals itself in its subjectivity and existential interests, which do not pass through such filters. As V.D. Gubin wrote: "Modern human being knows himself to the extent that he can realize himself." 16 And later: "I as spiritual life is a great immeasurable abyss, a special, in a way infinite universe that is located in some completely different dimension than the entire objective spatio-temporal world and the world of ideal objects." ${ }^{17}$ That is, the life of the soul, the 'inner human being' is a mystery in which the truth of being can be realized, but from which it distracts every moment of preoccupation with something external. Both K. Jaspers and M. Heidegger called this 'Existenz.' The term 'existential consciousness,' employed in existential philosophy, seems contradictory since Existenz is unable to realize itself, and existential reflection becomes possible only with the emergence of a spirit or 'spiritual Self' (as V. Frankl argued as well). That stream of the soul's life unfolds between the ego and the spiritual Self. Remaining in the power of the ego we will not become 'ourselves,' we will not save

16 V.D. Gubin, Life as a Metaphor for Being. Russian State University for the Humanities, Moscow 2003, 133.

17 Ibidem, 139. 
the 'soul alive,' we will not be able to comprehend, feel the makings of the Whole in us. And when the Whole will demand something, we wouldn't be able to hear its indistinct voice. Existenz will simply be wasted in vain on everything that is allowed by society, and even that which is not allowed, but is demanded by Existenz and pushed into the unconscious.

Contrary to Freud, in a nowadays life the very possibility of an intimate, open, 'naive,' trustful attention and experience of the world is repressed and displaced into the unconscious, not just biological and sexual impulses. The displacement of Existenz, this unnoticed daily crime of a rationalized society against humans, causes the 'loss of the vital contact with reality' (as Polish-French phenomenologist and psychiatrist Eugene Minkowski expressed it, describing suffering from schizophrenia caused by 'morbid rationalism'). We can talk about the pathological schizophrenic syndrome of modern technological civilization, where Existenz is suppressed from childhood while ego-consciousness is supported. The resulting conflict of reason and Existenz may be solved either by the complete suppression of feelings, which makes us social automats, computer machines not living, but functioning (G. Marcel); or it may be solved by 'existential rebellion,' the break-through of Existenz in youth revolt, counterculture, rock culture, psychedelic and sexual revolutions, all of which took place in the 1960s. It may also be solved in humanistic-oriented psychological 'self-realization groups' or in 'psychosis,' which existential psychiatrist R.D. Laing understood as an 'initiation ceremony,' a 'voyage from outer to inner,' from the 'false self' ('ego') to the 'true Self.'18 All these 'exits' can help human's 'existential rebirth' (R.D. Laing) ${ }^{19}$, an awakening of spontaneous vitality and feelings, hidden talents, thirst and interest in life. They can also restrain the 'big eye' of

18 R.D. Laing, The Politics of Experience and The Bird of Paradise, Penguin Books, London 1970, 108-119.

19 Ibidem, 97, 106. 
society inserted in us as an 'inner observer,' blocking vital impulses as 'wild,' 'childish,' 'abnormal.' In such an 'awakening to life,' one becomes a child again, just like Nietzsche dreamed. However, British existential psychotherapist E. van Deurzen warns against self-realization understood as "blind assertion of her own needs and interests." ${ }^{20}$ If one begins to follow individualistic 'wish,' rebelling against any general 'must' as external violence, a conflict with the 'wishes' of our inner circle is inevitable. Some of Deurzen's clients' family life even crashed as a result of such 'psychotherapy.'21 Therefore, we claim that after the 'existential rebirth' a second 'spiritual birth' is necessary. For, as K. Jaspers warned: "Irrational Existenz which rests upon feeling, unquestioned impulse, instinct, or whim, end up as blind violence (...) lost in the mere particularities of contingent empirical existence in a self-assertion unrelated to Transcendence, it ceases to be Existenz."22

\section{SPIRITUAL BIRTH}

Existential thinkers insist on the imperative of 'being yourself.' It is necessary not only to 'allow the other to be' (G. Marcel), but also to allow your hidden self to be. To quote J. Tischner: "Bergson wrote about 'deep Self' and 'superficial Self,' about free actions that open 'in the depths of consciousness' and come 'out' from the shell of the 'superficial Self' in unforeseen actions." ${ }^{23}$ For Tischner this is a dramatic process: something that I do not know is happening, and that is possible only in some special space which he calls 'agatological,' or the 'matrix of the human': "The paradox of a human being is that on

20 E. van Deurzen, Existential Counselling \& Psychotherapy in Practice, 2 ed., Sage, London 2002, 17.

21 Ibidem, 11-17.

22 K. Jaspers, Reason and Existenz, trans. W. Earle, Noondey Press, New York 1957, 68.

23 J. Tishner, Filozofia Dramatu. Spór o Istnienie Człowieka, Wybrane, tom. 2, trans. V. Tverdyslov, ROSSPEN, Moscow 2005, 400. 
the one hand he 'has already been born' (has become born), and on the other, he 'gives birth to himself.' Basing on the analysis we know: 'to give birth to thyself' is to find ourselves in the agatological space and thanks to it. It is the maternal space, its matrix." 24

The dramatic dimension of such a birth of a unique Self is caused by a certain force in a human being. To quote Marcel, this force is a 'higher reality' "which in the depths of me is greater than myself." 25 Minkowski calls this power 'superindividual, ${ }^{26}$ which, although it surpasses me, is the very "mine" in me. We call this force a "spiritual Self,' an independent authority not at all reducible to consciousness and intellect, and which acts as a kind of midwife in the birth of the existential authenticity of the human being as a personality. As for the agatological space, in our view the 'matrix of the human,' the space of Good and benevolence in which birth occurs is culture.

The sphere of culture is a 'different place,' in addition to the unfreely given reality. You need to literally 'stick to culture' and live in culture for many years in parallel with life in society. However, under the condition of genuine being in culture as a 'different place,' I have a chance to become a different, transformed, a truly spiritual being. The transformed human being is able to transform, humanize, and saturate with spiritual intentions the 'raw,' unhumanized reality. But so that one's strength does not run out, one must now and then cling to mother-culture, like Antaeus to Earth.

The birth of the spirit in the human being is a mystery. Already in archaic societies it was customary during initiation ceremonies to put a human being in a hopeless situation, from which she would be able to escape through the sudden 'possession by the spirit,' (of the Ancestor). Of course, mythological and religious narrations, as well as narrations

24 Ibidem, 402.

25 G. Marcel, Etre et Avoir, vol.I. Journal Metaphysique, Aubier, Editions Montaigne, Paris 1968, 210.

26 E. Minkowski, Lived time. Phenomenological and Psychopathological Studies, trans. N. Metzel, Northwestern University Press, Evanston 1970, 44. 
of secular culture, will differ, but in all of them the emergence of the spirit means the radical transformation of the human being, a decisive victory over the ego with its instinct of self-preservation. The strength of human being is as if increased tenfold at that very moment. This can be compared with the transformation of the behavior of photons in a laser beam in comparison with ordinary light. Of course, for a modern human being such a transformation comes at a high price. One could talk here about existential crises, noting that a way out of the crisis is accompanied by a change in worldview values and the very way of experiencing the world. Unfortunately, existential philosophers and psychotherapists do not usually emphasize the enormous role of culture. Except for E. Minkowski, who says that a spiritually born human being experiences a living spiritual connection with thousands of invisible interlocutors and his own voice enters an 'approbative murmur' of an invisible 'sphere of the spiritual community' "that surpasses me and guides me but which, irrational in its essence, cannot be detached from me or be made to be anything more precise." 27 Minkowski speaks about this sphere as the community of most human among humans who ever lived, which prompts us at the decisive moment the right thing to do that will not be my private, but a universal, 'ethical act.' According to Minkowski, the spiritual dimension is not 'given' initially, but requires a 'second birth.' Thus, each human being is a link in the continuous chain of spiritual evolution towards the maximum embodiment of humanity in thyself.

R. Ingarden calls this spiritual sphere 'culture.' He says that a human being lives at the junction of two worlds: the 'world of nature,' and the 'specifically human world' or the 'world of culture,' which is the world of values: "not of the relative values relating to life needs (for example, food) or pleasures (good health, enjoyment), but of the values, absolute in their immanent properties, although their implementation depends on the creative potential of a human 
being, in a word, of moral and esthetic values. But human being cannot find these values simply in nature, in the material world. He must create real conditions for their emergence and appearance in this world. Due to his special ability to present their qualities, he is able to create on the basis of the real world (...) a new world - the world of human culture in which values appear."28

The world of culture turns out to be a 'womb' in which the spirit of the personality ripens, and the latter turns out to be a source of universalizing intentions that appeal both to ego and Existenz. We call personality a unique unity of the universal and the individual. However, achieving such a unity is a difficult problem. Especially in the technologized-rationalized ('enchanted' according to M. Weber) world, in which the universal is replaced by the abstract-general, and the unity and uniqueness of the living life are reduced.

When trying to understand the spiritual principle of personality, we face a kind of paradox: the universalizing intentions of the spirit can neither be separated from culture and values nor fully identified with them. K. Rahner said: "being a personality means that the subject has thyself as such in a conscious and free connection with the whole." ${ }^{29}$ It is the world of culture that must give humans a symbol of such a Whole. Otherwise, instead of the 'dead gods' they will receive their ideological surrogates from society. Postmodernism, trying to avoid the dictatorship of ideologies, creates a simulacrum of absolute individual freedom in an indeterminate world, Chaosmos. Such a nihilistic answer is opposite to an understanding of freedom as responsibility, as a conscious restriction of one's freedom, as a search for a self-determination of one's behavior which proceeds not from randomness and arbitrariness, but from questioning the truth of being. This is a truly human way of being, requiring the presence of a symbolic

28 R. Ingarden, Książeczka o Człowieku, Wydawnictwo Literackie, Kraków 1987, 23.

29 K. Rahner, Human Being as a Personality and Subject, in: Theology of Personality, Biblical Theological Institute, Moscow 2013, 216. 
Whole, and even if it does not exist as formalized concepts of God, Reason, Absolute, it is still necessary. As Frank1 stated: "the spiritual basis of human existence, however, is ultimately unconscious." 30 This way of being can be called self-determination through the Whole, that is, a kind of conscious and unconscious dialogical correlation of individual existence with the being of the Whole. In essence, such self-determination is nothing but teleology, without which it is impossible to understand the existence of complex living organisms, and even less so of humans. In humans such self-determination must be conscious and proceed from their free will. However, the Whole cannot be represented in a rationally thinking consciousness. It can be grasped only intuitively and symbolically, and the spirit is the body of such a different consciousness. N. Berdyaev, struggling with all kinds of objectification (to which he attributed culture as well), rightly asserted that personality is not at all subject to any whole: "Transcension does not mean that personality is subordinated to any whole whatever, enters as an integral part into any collective reality whatever, or is related to the highest other, to a highest being, as to a master." 31 Of course, personality is not a part subordinated to the Whole, but she participates in a Whole and voluntarily allows it to participate in her life. Moreover, in the course of such co-participation, she becomes a symbolic representative of a Whole. Although such an understanding does not belittle personality, it does not allow us to absolutize 'creativity' and 'freedom' either. Berdyaev focused on personality and her creativity, while we focus on Being which is being with others, in the world, in its involvement in the Whole. Unlike Berdyaev, we argue that we need not be afraid of objectification (it is inevitable). We need to be afraid of the consent of a human being to objectification, with her functioning as a social thing. One should

30 V. Frankl, The Unconscious God. Psychotherapy and Theology, Hodder and Stoughton, London 1977, 30.

31 N. Berdyaev, Slavery and Freedom, trans. R.M. French, Geoffrey Bles, The Centenary Press, London 1944, 30. 
not be afraid of culture as an alleged source of violence - quite in the spirit of Freud and postmodernism. One needs to be afraid of eliminating culture as a 'second reality' in which one can realize one's at least potential humanity. For then one becomes a prisoner of the 'first reality' which has turned into a matrix, a closed ('final') system, and the possible comfort of an individuum is bought at the cost of renouncing freedom. To quote Rahner again: "The final system cannot imagine itself as a whole. (...) It does not ask questions about herself, it is not a subject. The experience of radical doubt and calling a human being into question is an achievement impossible for the final system as such." 32

Isolated from Being, my Self turns out to be pure consciousness (Sartre's 'nothingness'). Being, isolated from me, turns out to be a totality in which any 'self' dissolves as a part in the Whole conceived as a General, from which a secondary 'particularity' is derived. However, we understand Being as such a Whole with which the individual self, like a micro-whole, enters into a relationship. Being is a meeting place for You and I. The shared Being becomes our mutual co-being. In this sense, the ontology of love introduced by the Orthodox theologian I. Zizioulas, rather than the ontology of the essence as the overlying essence (Plato's idea of a buman being) or the underlying essence (Aristotle's idea of the nature of mankind, specie) resembles our own view. In both cases, it is an ontology of relations that creates "absolute and unique identities": "if we want to embed the particular in the ontology we must introduce relations into the essence itself, make being relational. Trying to identify a concrete thing, we must make it a part of the relationship, and not isolate it

32 K. Rahner, Human Being as a Personality and Subject, in: Theology of Personality, Biblical Theological Institute, Moscow 2013, 215. 
as something separate (...) This is a condition for constructing an ontology of personality." 33

Therefore, what is important is neither $I$ in thyself, nor You as the Other, but what is between us, our mutual connection, i.e. Being. In this case, All-Being as the Absolute appears Third in the relationship between I and You. Or else, as a space for our meeting. I as a particular concrete personality can communicate with You as the other concrete personality only if there is something common in us and between us. In Christian anthropology, this common element is the Prototype a hypostasis, of which every human being is an embodiment. In our understanding, the common element between us and within each of us is Being. Only in Being am I born as a personality. If the ego is the representative of society, personality is the representative of Being, its subject. Being as the common element between us means that only through participation in Being, establishing a relation with it, I can establish a relation with the other. Being as the Absolute enables a relationship with the non-absolute other. Therefore, an 'ontology of relations' is the basis for an 'ontology of personality.'

\section{CONCLUSION}

To be means to participate in Being, to be responsible both for one's own being and for the being of Being. Every human being is on a journey from existence as a passive presence, as a 'living thing' that can be manipulated, to Being. Unfortunately, instants of genuine Being do not happen often. In such instants, we gain unity with the whole world through acts of transcending and experience the fullness of Being, which cannot be communicated to others. We feel the joy of realizing our problematic essence, which we always

33 I. Zizioulas, What does it Mean to be a Personality: to the Question of the Ontology of Personality, in: Theology of Personality, Biblical Theological Institute, Moscow 2013, 203-204. 
seek, constantly identifying and redefining ourselves. On this path to Being we need culture, which in its spirit is a kind of compass needle sensitively responding to deviations from the Path. Now that culture has lost its necessity, its ideological power, it requires our voluntary 'existential choice' and the recognition of its indispensability on our way from existence to Being.

The spiritual Self of human being exists in a double connection with the transcendent Whole and with Existenz as an expression of the innermost uniqueness of the Self. The unity of spirit and Existenz, the unity of life and culture, the transcendence of the ego which expresses the interests of biology and society - all this comes at the price of constant struggle, dialogue, and compromises. But all the same, moments of integrity and a sense of the Path emerge. For only on this path does one become completely human, a unique being, uniting in oneself all-humanity and all-Being.

\section{REFERENCES}

Berdyaev N., Slavery and Freedom, trans. from Russian R.M. French, Geoffrey Bles, The Centenary Press, London 1944.

Deurzen E. van., Existential Counselling \& Psychotherapy in Practice, 2 ed., Sage, London 2002.

Frankl V., The Unconscious God. Psychotherapy and Theology, Hodder and Stoughton, London 1977.

Gubin V.D., Life as a Metaphor for Being, Russian State University for the Humanities, Moscow 2003 (in Russian).

Gutner G., The Concepts of Personality and Communicative Universals, in: Theology of Personality, ed. A. Bodrov, M. Tolstolugenko, Biblical Theological Institute, Moscow 2013, 104-122 (in Russian).

Ingarden R., Ksiażeczka o Cztowieku, Wydawnictwo Literackie, Kraków 1987. Kant I., Practical Philosophy, trans. from German and ed. M.J. Gregor, Cambridge University Press, Cambridge 1996.

Kelle V.Zh., Culture and Freedom, Philosophy Journal (2008)1, 44-53 (in Russian). 
Krasicki Y., Mind and Other. Essays on Russian and European Thought, Russian Christian Academy for the Humanities Publishing House, St. Petersburg 2015 (in Russian).

Laing R.D., The Politics of Experience and The Bird of Paradise, Penguin Books, London 1970.

Marcel G., Etre et Avoir, vol.I. Journal Metaphysique, Aubier, Editions Montaigne, Paris 1968.

Minkowski E., Lived time. Phenomenological and Psychopathological Studies, trans. from French N. Metzel, Northwestern University Press, Evanston 1970.

Nietzsche F., The Will to Power, trans. from German W. Kaufmann, R.J. Hollingdale, ed. W. Kaufmann, Vintage Books, New York 1968.

Porus V., Crossroads of Methods. Experiences of Interdisciplinarity in the Philosophy of Culture, Canon + ROOI Rehabilitation, Moscow 2013 (in Russian).

Rahner K., Human Being as a Personality and Subject, in: Theology of Personality, ed. A. Bodrov, M. Tolstolugenko, Biblical Theological Institute, Moscow 2013, 210-217 (in Russian).

Tillich P., Religion and Secular Culture, The Journal of Religion 26(1946)2, 79-86. Tishner J., Filozofia Dramatu. Spór o Istnienie Cztowieka, Wybrane, tom. 2, trans. from Polish V. Tverdyslov, ROSSPEN, Moscow 2005 (in Russian).

Vizgin V., V. Prishvin and Philosophy, Center for Humanitarian Initiatives, Moscow, St. Petersburg 2016 (in Russian).

Zizioulas I., What does it Mean to be a Personality: to the Question of the Ontology of Personality, in: Theology of Personality, ed. A. Bodrov, M. Tolstolugenko, Biblical Theological Institute, Moscow 2013, 193-209 (in Russian).

ILLYA REYDERMAN

College of Arts named after M.B. Grekov; Free School of Philosophy and Culture

Odessa, Ukraine

ORCID: 0000-0001-8986-2122

ANASTASIIA ZINEVYCH

niokazin@yahoo.com

Free School of Philosophy and Culture

Odessa, Ukraine

ORCID: 0000-0003-4371-1198

DOI: 10.21697/spch.2020.56.2.06 